\title{
MATERIAL TEST ON STRAIN FRACTURE AND CRACK OPENING DISPLACEMENT BASED ON DIGITAL IMAGE CORRELATION METHOD
}

\begin{abstract}
J. BIAN' ${ }^{1}, Z X . G E^{2}$
As a machining technology, welding can cause serious accidents by overloading or operation mistakes. Through analyzing the causes of various welding accidents, we found that the major cause for damage imposed after welding parts are loaded is the fracture of materials. Therefore, studying the influence of welding residual stress on the fracture property of materials is of great significance. This paper applied the digital image correlation technique to study the fracture property of welding parts under the influence of welding residual stress. In addition, standard parts and welding parts were selected to carry out a contrast experiment. Room temperature tensile tests were performed on both standard parts and test pieces after residual stress measurement. Using displacement field and strain field data obtained through VIC-2D software, the stress intensity factor around the crack tip of each specimen under the conditions of small load was calculated and corresponding analysis was carried out.
\end{abstract}

Keywords: Digital image correlation method, crack, fracture, welding

\section{INTRODUCTION}

Microscopic cracks inside materials is the initial act of defects in both the material welding area [1] and material fatigue caused by variable load. Under the combined action of welding residual stress [2] and applied load, the microscopic crack increases constantly until it becomes a macroscopic crack, and the macroscopic crack then continues to expend, finally leading to the fracture of

\footnotetext{
${ }^{1}$ Jining Normal University Department of Computer Science, Gongnong Road, Jining District, Wulanchabu City, Inner Mongolia,012000, China; e-mail: bianjing0789@163.com

2 Jining Normal University Network Certer, 012000, China; e-mail: gezhx023@sina.com
} 
materials. The presence of residual stress in welded components will seriously affect the operational performance of the structure. Therefore, a study on the influence of welding residual stress on the fracture properties of materials [3-4] is of great significance. In recent years, with wide application of the digital image correlation method in material crack opening displacement tests, many domestic and overseas scholars have carried out related studies in this aspect.

For example, Gao H L, Jiang W, Liu H, et al. [5] obtained the crack opening displacement, crack mouth opening displacement and changing curve of neutral layer position, along with load variation through calculation and predicted the trend of crack propagation in 2014. The results were found to be consistent with the actual material crack activity. Qian X, Zhang S, Swaddiwudhipong S, et al. [6] studied the stable crack expansion resistance automatic measurement technology based on the digital image method and built a stable crack growth measurement hardware system based on a Charge Coupled Device (CCD) Digital Camera with a system analysis of various test methods on fracture toughness of metal material in 2014. Ghorbani R, Matta F, Sutton M A, et al. [7] analyzed and summarized the fracture failure mode and failure mechanism of bamboo wood as well as quantitatively measured the fracture toughness of bamboo wood based on images on the surface of the specimen and the displacement field and strain field measured by the Digital Speckle Correlation Method (DSCM) in 2014.

The digital image correlation method (DICM) applied in this study is a technology which processes images by computer. TEMA DIC 2D consists of CCD cameras, lenses, software analysis, holder and a light source which is suitable to be applied to tension, compression and bending tests on flat materials or structures. Real-time single point or multi-point strain or displacement data can be obtained without the help of a strain gauge, including axial strain, lateral strain, shear strain, principal strain, axial displacement and horizontal displacement. Digital image correlation technique captures and records the digital images on the object surface before and after deformation through the camera [8] and then obtains the displacement of each point on the surface of the measured object caused by strain fracture through a related matching operation on the obtained images. 


\section{MATERIALS AND METHODS}

\subsection{EXPERIMENTAL METHOD AND PROCESS}

In fracture mechanics, the most commonly used fracture parameters mainly include stress intensity factor $\mathrm{K}$, integral $\mathrm{J}$ and crack tip opening displacement. This study carried out related processing on images obtained from a digital image correlation (DIC) test system through the tensile experiment on a compact tension specimen and obtained the changes of the above parameters under the action of welding residual stress. A relevant experiment scheme was designed.

Austenitic stainless steel 304 [9-10] was selected as the experimental material. According to the national standard, two types of specimens are used in fracture mechanics: a three-point bending specimen and a compact tension (CT) specimen. After a comprehensive comparison, this study selected the compact tension specimen as the test specimen.

According to the standard, there were precracks in the specimen which include machining cracks in the front part and fatigue cracks in the middle part. Since the fatigue crack prefabrication process during the welding treatment can lead to the redistribution of the welding residual stress field on a specimen surface, to reduce this impact, fatigue prefabrication was changed to mechanical processing prefabrication [11]. This study applied the mechanical processing technique of Wire cut Electrical Discharge Machining (WEDM), and the cutting crack selected has a length of $2 \mathrm{~mm}$ and a width of $0.15 \mathrm{~mm}$.

Welding treatment needs to be carried out on specimens after preliminary machining based on experimental scheme. Contrast test requires the processing of multiple specimens and same welding process on each specimen. As for the welding position, it is treated as a variable. The welding seam at different positions determines the residual stress field distribution of the crack tip region.

Each set of experiments contains three specimens, all of which have a thickness of $10 \mathrm{~mm}$ and include: one un-welded specimen; one specimen with a welding direction perpendicular to the crack direction and one specimen with a welding direction parallel to crack direction. They were designated as $\mathrm{A}, \mathrm{B}$, and $\mathrm{C}$, respectively.

Manual argon shielded welding was selected for the welding process. Since the specimen was relatively thick, according to the welding standard, an "X" shaped notch was opened on the welding parts. Two pieces of stainless steel plates were connected through panel butt welding. Welding process parameters are shown in table 1. 
Table 1. Welding parameters

\begin{tabular}{|c|c|c|c|}
\hline Welding parameter & $\mathrm{A}$ & $\mathrm{B}$ & $\mathrm{C}$ \\
\hline Voltage/V & \multicolumn{3}{|c|}{$15.4 \mathrm{~V}$} \\
\hline Ampere/A & \multicolumn{3}{|c|}{$\varphi_{2 \mathrm{~mm}, 304 \text { stainless steel }}$} \\
\hline Welding rod & \multicolumn{2}{c|}{} \\
\hline Welding velocity/mm/s & \multicolumn{2}{c|}{ " type, with four courses of welding } \\
\hline Groove & \multicolumn{2}{c}{}
\end{tabular}

The measuring equipment for the fracture parameters includes a specimen loading device and a digital image correlation measurement system. The computer controlled electronic universal testing machine was selected as the loading device, while a Charge Coupled Device (CCD) industrial camera and image capture card [12-13] were used in the digital image correlation measurement system. The captured images were input into the computer and a correlation analysis was carried out by application software developed based on the principles of the digital image correlation method.

\subsection{TEST PROCEDURE}

\subsubsection{PREPARATION OF SPECKLE PATTERN}

This study applied the spray painting method for preparation of speckles. Meanwhile, a tensile test was carried out on specimens after the residual stress test. A tensile test can be applied to materials which do not chemically react with the spray paint, such as metal, ceramic, etc. The specimen surface needs to be cleaned before spraying and then well shaken black and white flat lacquer was sprayed onto the specimen surface. The spraying order has great impact on the quality of the speckle pattern. Firstly, white flat lacquer was sprayed onto the specimen surface as a base color [14]. Then, black flat lacquer was sprayed to form equally distributed black spots on the white under layer. To ensure highly precise calculation results, the spots must be clear and legible, with appropriate sizes. Taking into account that the specimen tensile process will produce large deformations, speckles of the cracked section must be stable enough [15] so that they will not fall off. A speckle completed specimen is shown in figure 1 .

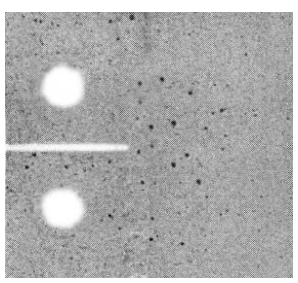

Fig. 1. Speckle pattern of a specimen 
A specially designed fixture was applied to fix the prepared specimens on the universal testing machine so that the tensile experiment of CT specimens could be carried out. The fixture operates easily and can fix the specimens well by rotating the joystick, which plays a significant role under the situation of frequent workpiece exchange operations. It can cut down the preparation time considerably and improve production efficiency, with its work efficiency tripled compared with normal fixtures.

\subsubsection{PiXel equivalent Calibration}

To start the electronic universal testing machine, the cross beam position needs to be adjusted firstly to make it easy for specimen clamping. Then, the image acquisition system was connected to an image capture card and a computer. Meanwhile, the camera [16] system was debugged and parameters were set up to achieve a clear vision. Afterwards, the specimen was fixed on the fixture and the lenses of the CCD industrial camera were adjusted to directly face the specimen surface to observe the speckle image presented in the computer display. The brightness of the halogen light source was adjusted until clear bright images were obtained.

Since cameras record the image information in the form of pixels while the calculation and analysis process of the Vic-2D software needs to convert pixels into length information, calibration needs to be carried out on pixels and length before the experiment so as to determine the specific relationship between the two. Pixel equivalent is a major parameter in vision the system which has a decisive impact on the final measurement accuracy. Hence, designing a pixel equivalent calibration with noise immunity that is easy to operate is essential. The specific operation was as follows: firstly, a measuring scale with high precision was fixed on the specimen surface and the image of this moment was collected and put into the computer software. Then, the actual distance between the two points on the image was calibrated while the pixel distance between the fixed points was automatically identified by the software. The transformational relation between the two is as follows:

Pixel equivalent $\mathrm{D}=$ actual distance $\mathrm{L}$ between two points $(\mathrm{mm}) /$ pixel L' between two points (pixel)

\subsubsection{SPECIMEN TENSILE EXPERIMENT}

Before the experiment, the loading equipment needed to be adjusted properly. Firstly, the inhibiting device of the testing machine was adjusted to avoid the intermediate transverse girder touching other parts in movement. Secondly, relevant parameters needed to be set up and the test method 
selected. Relevant data needed to be filled out, including the cross section width, thickness etc. After adjustment, the tensile test was carried out.

The experimental steps are as follows: firstly, preload was carried out on specimens by force speed mode so as to increase the test force gradually. Small acting force was preloaded, with a loading speed of $0.2 \mathrm{KN} / \mathrm{s}$, and the maximum preloading acting force was kept at the level of $1 \mathrm{KN}$. The purpose of preload is to fix the position of the specimen and fixture for easy calibration. At the same time, the image acquisition system started simultaneously with the loading system. After the preloading, continuous loading was set up on the testing machine until it reached the maximum set loading value. During the process, the CCD industrial camera kept shooting and collecting images. It is important to note that the corresponding picture serial number of specific loads must be well recorded for post-processing analysis.

\subsubsection{PROCEDURES FOR THE DETERMINATION OF RESIDUAL STRESS}

In this paper, the XSTRESS 3000 type residual stress measurement instrument was applied to measure the residual stress on the specimen surface. Firstly, a simple wiping treatment was performed on the specimen surface. Then, the location point on each specimen to be measured was selected and the equipment was set up and calibrated accordingly, thus the residual stress corresponding to each location point was measured.

\section{EXPERIMENTAL RESULTS AND ANALYSIS}

\subsection{MEASUREMENT RESULTS OF WELDING RESIDUAL STRESS}

Welding residual stress, as a stress vector [17], can be divided into components of three directions. This study sets out the various forms of residual stress in components. Firstly, a rectangular coordinate system was established. On the surface of the welded specimen, the direction parallel to the welding line was defined as the $\mathrm{X}$-axis direction and the direction perpendicular to the welding line was defined as the Y-axis direction, and specimen thickness was defined as the Z-axis direction. The apex of the crack tip was selected as the origin of coordinates. Thus, the welding residual stress was decomposed into components of three directions. The component parallel to the $\mathrm{X}$-axis direction was called transversal stress component, denoted by ${ }^{\sigma_{x}}$; the component perpendicular to the Y-axis direction was called longitudinal stress component, denoted by ${ }^{\sigma_{y}}$; the 
component in the thickness direction was called thickness component, denoted by $\sigma_{z}$. Since the thickness component and transverse component have little impact on materials, this study selects the longitudinal stress component which plays a leading role in material fracture as the object of study.

Below are the partial results of the residual stress of welding specimen and the reference coordinate system is shown in figure 2 .

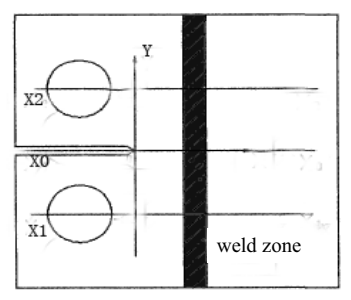

Fig. 2. The longitudinal stress distribution along $\mathrm{X} 1 \mathrm{X} 1$ at the point of $\mathrm{Y}=22$ (when the welding line is perpendicular to the crack direction)

From table 2 and figure 3, we can see the longitudinal residual stress field distribution on the surface of specimen A. Longitudinal residual stress [18] in the area near the edge of the bead had a maximum value and it appeared in the crack line. With the increase of welding edge distance, the longitudinal residual stress transferred gradually from tensile stress to pressure stress and there was a maximum value of residual compressive stress. If the residual stress is positive in the area near the crack tip, then the area is in the residual tensile stress zone.

Table 2. Residual stress measured value of specimen A (unit: MPa)

\begin{tabular}{|c|c|c|c|}
\hline Distance with the Y axis (mm) & X0X0 measured value & $\begin{array}{c}\text { X1X1 measured } \\
\text { value }\end{array}$ & X2X2 measured value \\
\hline 14 & 97.2 & 40.1 & 39.9 \\
\hline 15 & 142.1 & -58.1 & 5.9 \\
\hline 20 & -9.2 & -182.3 & -102.9 \\
\hline 22 & -4.5 & -131.9 & -205.6 \\
\hline 24 & -167.5 & -35.6 & -231.9 \\
\hline
\end{tabular}




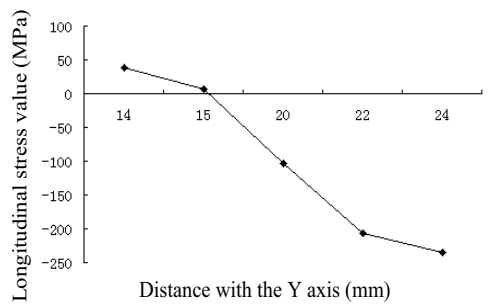

Fig. 3. Changes of the value of longitudinal residual stress on the surface of specimen A

From table 3 and figure 4, we can see that for specimen B, the longitudinal welding residual stress was negative in the area near the crack tip and the crack tip area was in a residual compressive stress state. The longitudinal residual compressive stress value in the crack line X0X0 was smaller than the value on both sides of the crack line, suggesting that the crack can release a part of the residual stress.

Table 3. Measured value of residual stress of the specimen B (unit: MPa)

\begin{tabular}{|c|c|c|c|}
\hline Distance with the Y axis (mm) & X0X0 measured value & X1X1 measured value & $\begin{array}{c}\text { X2X2 measured } \\
\text { value }\end{array}$ \\
\hline 3 & -65.2 & -231.9 & -236.9 \\
\hline 5 & -337.9 & -146.9 & -283.1 \\
\hline 7 & -333.8 & -166.7 & -257.9 \\
\hline 9 & -126.5 & -78.6 & -221.6 \\
\hline 11 & -150.9 & 34.9 & -236.8 \\
\hline
\end{tabular}

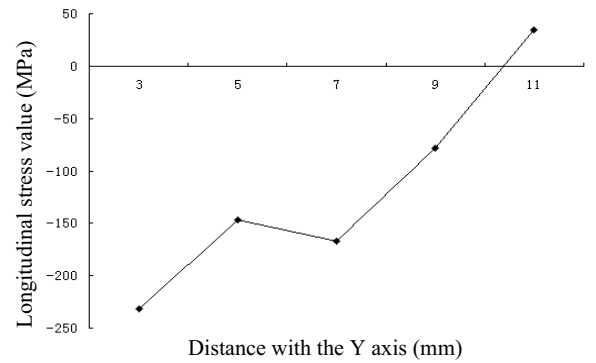

Fig. 4. Changes of the value of longitudinal residual stress on the surface of specimen B

From table 4 and figure 5, we can see that the longitudinal residual stress distribution of specimen C was similar to those of the above two welding parts. The area near the welding bead was the residual 
tensile stress area and the size of the longitudinal residual stress was close to material yield strength. Since the specimen crack [19] was in the center of the welding bead, the measured value of longitudinal residual stresses showed large fluctuations in distribution.

Table 4. Measured value of residual stress of specimen C (unit: MPa)

\begin{tabular}{|c|c|c|c|}
\hline Distance with the $\mathrm{X}$ axis $(\mathrm{mm})$ & Y0Y0 measured value & $\begin{array}{c}\text { Y1Y1 measured } \\
\text { value }\end{array}$ & Y2Y2 measured value \\
\hline 5 & 113.1 & 154.8 & 117.4 \\
\hline 8 & 190.1 & 175.6 & 43.9 \\
\hline 11 & -16.8 & -20.9 & -79.6 \\
\hline 14 & -153.9 & -214.9 & -125.4 \\
\hline 17 & -168.2 & -356.1 & -196.3 \\
\hline
\end{tabular}

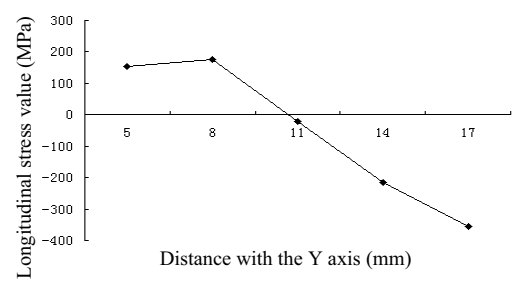

Fig. 5. Changes of the value of longitudinal residual stress on the surface of specimen C

Through comparison of the measurement results of residual stress of each specimen, the actual residual stress distribution can be obtained as follows:

(1) Centered on the straight line where the welding line lies, longitudinal residual stress in the region near the welding bead reached a peak value. The stress value at the center of welding line was smaller than the peak value, which is to say, the maximum residual stress does not appear in the weld at the center, but is in the junction of weld and base metal.

(2) Extending from the center to the ends of the weld, the longitudinal residual stress experienced a gradational transition from residual tensile stress to residual compressive stress. With the increase of distance, the longitudinal residual stress was transferred to residual tensile stress again and the maximum residual stress was in the center. This showed that compared with remote areas, the welding zone experienced rapid heating before rapid cooling, and the residual compressive stress of the heating process was not enough to offset the residual tensile stress of the cooling process, which leads to the presentation of residual tensile stress in the welding zone; while the results were opposite in the area distant from the weld. 
(3) Residual tensile stress values at the center of the welding bead were close to the yield strength of material while part of the residual compressive stress values exceeded the limit of yielding, suggesting that there was a material hardening phenomenon and the material strength was improved.

Though there were some errors in the measurement of welding residual stress which was unavoidable, the measured values of different specimens are basically the same on the trend and law of value distribution, suggesting that the measured values of residual stress in this study are reliable and can basically reflect the distribution law of residual stress.

\section{Processing of COLleCted imageS}

During the loading process of the universal testing machine, the CCD industrial camera performed a consecutive collection of deformed images on the surface of the specimens. For each specimen, the total number of collected images varied from 800 to 20,000 . The digital images collected by the experimental process were input into the Vic-2D software. Then, after a suitable parameter analysis, the results were obtained.

By comparing cloud pictures of the partial results obtained from software processing, we found that with the increase of load, the displacement field of the specimen increased, with a maximum $U$ directional displacement of $0.031 \mathrm{~mm}, 0.274 \mathrm{~mm}$ and $0.842 \mathrm{~mm}$ respectively. The Mises strain values [20] at the crack tip on the surface of the specimen were $0.00748,0.0396$ and 0.082 , respectively, with the value distribution similar to the displacement field distribution, i.e., both values increased with the increase of load.

Mises stress is an equivalent stress based on shear strain energy and its value is as follows: $\sigma=\left(1 / 2(\sigma 1-\sigma 2)^{\wedge} 2+(\sigma 2-\sigma 3)^{\wedge} 2+(\sigma 3-\sigma 1)^{\wedge} 2\right)^{\wedge}(1 / 2)$

in the equation, $\sigma 1, \sigma 2$ and $\sigma 3$, respectively, refers to the first, second and third principal stress, which is the fourth strength theory, also known as the distortion energy density theory, as well as the major cause for material yield. At the same time, the results showed that the distribution of Mises strain cloud picture had a certain regularity: At the crack tip, the cloud picture presented dark red and strain reached a maximum at the tip; while with the increase of distance with the tip, the cloud picture presented cricoids distribution layer upon layer, with the strain becoming smaller and smaller. The distribution under various loading conditions was similar with very small differences in value. This situation showed that when a crack specimen was under applied load, the biggest deformation may occur at the crack tip. Once the deformation reached a critical value, unstable propagation of the crack would appear starting from the tip and expand to other adjacent areas. 
Among the three components of strain, Eyy showed the same trend with the Mises strain. However, the cloud distribution of the other two components showed no obvious regularity. This suggested that under tensile load case, the strain values of CT specimens were mainly influenced by longitudinal strain Eyy. Below are the cloud pictures of the results near the crack tip of standard CT specimens at the loading of $20 \mathrm{kN}$. Here, $\mathrm{U}$ and $\mathrm{V}$ are the cloud pictures of the displacement component of specimens on $\mathrm{X}$ and $\mathrm{Y}$ direction; Exx, Eyy and Exy are strain component cloud pictures and Mises strain is the Mises strain, obtained through a double calculation.

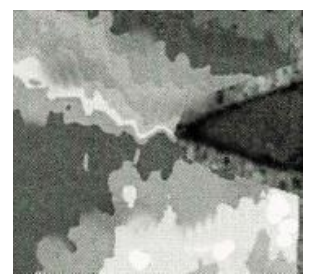

U

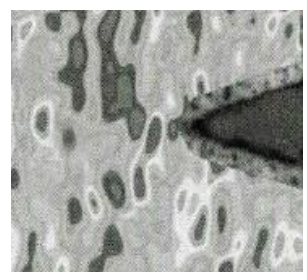

$\operatorname{Exx}$

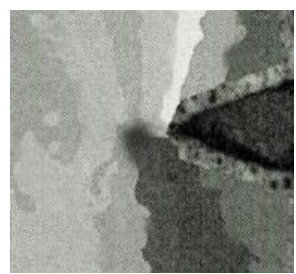

V

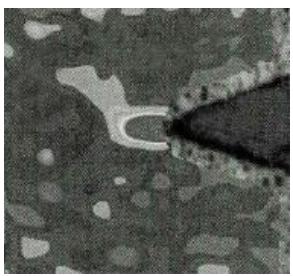

Eyy

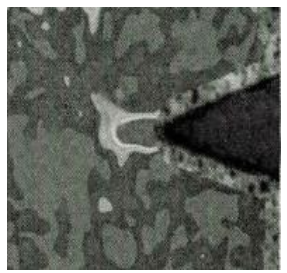

Mises strain

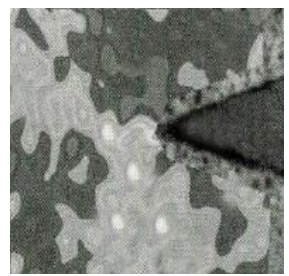

Exy

Note: figure $\mathrm{U}$ describes the displacement component cloud picture of the specimen on $\mathrm{X}$ direction; figure $\mathrm{V}$ describes the displacement component cloud picture of the specimen on $\mathrm{Y}$ direction; figure Mises strain describes the Mises strain figure; figure Exx, Eyy and Exy are strain component cloud pictures 


\section{ANALYTICAL CALCULATION OF FRACTURE PARAMETERS}

\subsection{CALCULATION OF STRESS INTENSITY FACTOR}

Only pure I type cracks were considered under the condition of plane stress within the range of linear elasticity; the displacement field, stress field and strain field of I type cracks in crack tip region under the action of tensile stress were respectively as follows:

Displacement field

$$
\begin{aligned}
& u=\frac{K}{G(1+v)} \sqrt{\frac{r}{2 \pi}} \cos \frac{\theta}{2}\left[(1-v)+(1+v) \sin \frac{\theta}{2} \sin \frac{3 \theta}{2}\right] \\
& v=\frac{K}{G(1+v)} \sqrt{\frac{r}{2 \pi}} \sin \frac{\theta}{2}\left[2-(1-v) \cos ^{2} \frac{\theta}{2}\right]
\end{aligned}
$$

Stress field

$$
\begin{aligned}
& \sigma_{x}=\frac{K}{\sqrt{2 \pi r}} \cos \frac{\theta}{2}\left[1-\sin \frac{\theta}{2} \sin \frac{3 \theta}{2}\right] \\
& \sigma_{y}=\frac{K}{\sqrt{2 \pi r}} \cos \frac{\theta}{2}\left[1+\sin \frac{\theta}{2} \sin \frac{3 \theta}{2}\right] \\
& \tau_{x y}=\frac{K}{\sqrt{2 \pi r}} \cos \frac{\theta}{2} \sin \frac{\theta}{2} \cos \frac{3 \theta}{2}
\end{aligned}
$$

According to the above strain field equations, we can obtain the crack tip strain fields under different load conditions through Vic-2D measurement. Take the values of appropriate locations into the above equations and we can obtain the corresponding stress intensity factor $\mathrm{K}^{I}$. Since the strain field at $\mathrm{Y}$ direction was obvious among all measured strain fields, we take it to calculate $\mathrm{K}^{I}$. Descartes rectangular coordinate system [21] was established, taking the crack tip as the origin of coordinates and the crack propagation direction as the $\mathrm{X}$ axis. Based on this coordinate system, a polar coordinate system was established. A series of data points $\varepsilon_{y}(r, \pi)$ of appropriate locations on the crack were selected to calculate the value of $\mathrm{K}^{I}$. 
(6)

$$
K=\frac{\sqrt{2 \pi r} \cdot E \cdot \varepsilon_{y}}{\cos \frac{\theta}{2}\left[(1-v)+(1+v) \sin \frac{\theta}{2} \sin \frac{3 \theta}{2}\right]}
$$

For stainless steel 304, $\mathrm{E}=193,000 \mathrm{MPa}, \mathrm{v}=0.274, \theta=\pi$. By taking different values respectively, corresponding $\mathrm{K}$ values can be obtained. Since the singular item of radius $\mathrm{r}$ remained, the above equation is only accurate in the area near the crack tip ( $r$ tends to zero). While in the area distant from the crack tip, the stress intensity factor $\mathrm{K}$ is no longer a constant value [22]. Therefore, the points we selected should be within a small distance from the tip, though it is difficult to guarantee. Thus, we applied the extrapolation method. Firstly, a fixed direction was selected near the crack tip. Then, different points on this direction were selected according to their distance $r$ from the tip and stress intensity factor values were calculated respectively. A K-r curve was obtained after curve fitting was carried out on these points. Finally, the point of intersection between the K-r curve and $\mathrm{Y}$ axis was calculated, which was just the stress intensity factor value we required, as shown in figure 6 .

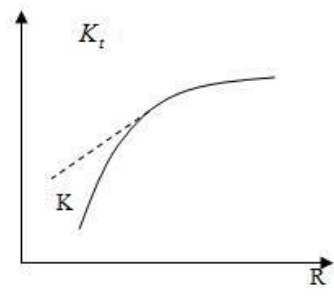

Fig.6. K-r curves

\subsection{CALCULATION METHOD AND RESULT ANALYSIS OF CRACK TIP OPENING DISPLACEMENT}

When a specimen contains a crack, Vic-2D software can be used to get the crack opening displacement (COD). After certain treatment, the crack tip opening displacement (CTOD) can be extracted. 
10mm All specimens CTOD value distribution

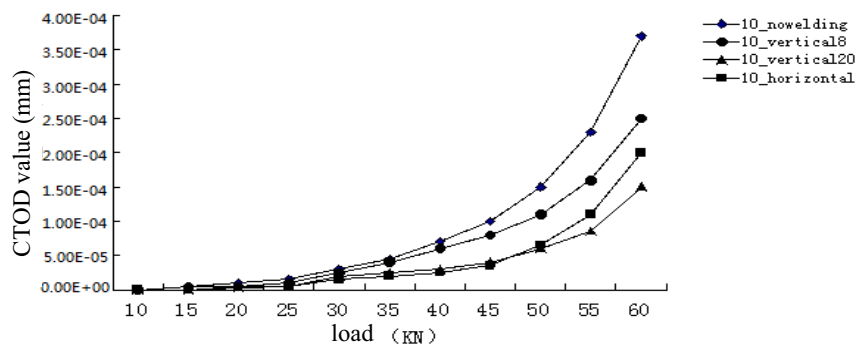

Fig. 7. CTOD value distribution of $10 \mathrm{~mm}$ specimens

Firstly, an original image with clear cracks should be selected because this part of the operation must be carried out on the original image. Secondly, the position of the crack tip should be determined, which is the key point since software can only carry out accurate data processing calculation when the position of the crack tip is correct. However, in the actual operation process, the determination of the crack tip is very difficult, which requires accurate operation and reasonable treatment. In this study, a small area [23] near the crack tip was selected first. Then, the positioning coordinates of all points in the area were exported to accurately determine the crack tip position. Thus, CTOD can be observed.

For COD calculation results, since not all of the data are valuable because the COD values change along with the change of load [24] in the experimental process, part of the CTOD values under specific load conditions were selected.

From the CTOD distribution diagram of each specimen, it can be seen clearly that [25], under the same load, difference on CTOD values between different specimens was significant. With the increase of tensile load, CTOD value increased significantly. At the same time, it showed that, differently from the stress intensity factor under small load, there was no linear relationship [26] between CTOD and load. Instead, it was an approximate parabolic relationship. Considering the physical meaning of CTOD, the crack tip opening was not obvious and tended to be mild when the material was under small load, suggesting that small load does not affect the safety of the materials which contain cracks. However, with the linear increase of load, CTOD presented a trend of sharp increase, which showed that under large load cases, materials containing cracks cannot ensure a safe and reliable work and the danger coefficient increases sharply. Therefore, we need to pay attention to this so as to reduce the perniciousness in actual production. 


\section{Conclusion}

This study applied the digital image correlation technique to study the fracture property of welding parts under the influence of welding residual stress. In addition, standard parts and welding parts were selected to carry out a contrast experiment and speckle images on specimen surface were collected with the digital image correlation measurement system. Through analysis of the calculation results of welding residual stress and CTOD, we found that the fracture parameters of each specimen were significantly influenced by welding residual stress under small load while the effect was not obvious under large load, suggesting that under the condition of large load, applied load becomes the dominant factor that affects fracture properties of materials rather than the welding residual stress. Due to limited equipment and materials, there are still some deficiencies in this experiment. As we gain more experience, we will make more comprehensive test studies in the future. 


\section{REFERENCES}

1. V. Samardzic, E. S. Geskin, G. A. Atanov, et al. Investigation of the Material Welding Using the High-Speed Liquid Impact. Journal of Materials Engineering \& Performance, 17(3):369-375, 2008.

2. D. Deng, H. Murakawa. Numerical simulation of temperature field and residual stress in multi-pass welds in stainless steel pipe and comparison with experimental measurements. Computational Materials Science, 37(3):269-277, 2006.

3. L. Chen, G. R. Liu, K. Zeng, et al. A novel variable power singular element in G space with strain smoothing for bi-material fracture analyses. Engineering Analysis with Boundary Elements, 35(12):1303-1317, 2011.

4. Z. Zhuang, P. E. O'Donoghue. Determination of material fracture toughness by a computational/experimental approach for rapid crack propagation in PE pipe. International Journal of Fracture, 101(3):251-268, 2000.

5. H. L. Gao, W. Jiang, H. Liu, et al. The Measurement of the Fatigue Crack-tip Displacement and Strain Fields under High Frequency Resonant Loading Applying DIC Method. Applied Mechanics \& Materials, 710:83-90, 2014.

6. X. Qian, S. Zhang, S. Swaddiwudhipong, et al. Temperature dependence of material length scale for strain gradient plasticity and its effect on near-tip opening displacement. Fatigue \& Fracture of Engineering Materials \& Structures, 37(2):157-170, 2014.

7. R. Ghorbani, F. Matta, M. A. Sutton. Full-Field Deformation Measurement and Crack Mapping on Confined Masonry Walls Using Digital Image Correlation. Experimental Mechanics, 55(1):227-243, 2014.

8. Chu et al. Applications of digital-image-correlation techniques to experimental mechanics. Experimental Mechanics, Volume 25, Issue 3, Pages 232-244, September 1985.

9. N. Arivazhagan, Singh S., Prakash S., et al. Investigation on AISI 304 austenitic stainless steel to AISI 4140 low alloy steel dissimilar joints by gas tungsten arc, electron beam and friction welding. Materials \& Design, 32(5):3036-3050, 2011.

10. L. M M T, O. Sanz, M. A. Centeno, et al. AISI 304 austenitic stainless steel monoliths: Modification of the oxidation layer and catalytic coatings after deposition and its catalytic implications. Chemical Engineering Journal, 162(3):1082-1090, 2010.

11. K. Narita, M. Niinomi, M. Nakai, et al. Development of thermo-mechanical processing for fabricating highly durable $\beta$ mathContainer Loading Mathjax -type $\mathrm{Ti}-\mathrm{Nb}-\mathrm{Ta}-\mathrm{Zr}$ rod for use in spinal fixation devices. Journal of the Mechanical Behavior of Biomedical Materials, 9:207-216, 2012.

12. S. Derrouich, K. Izumida, K. Shiiya. A combination of monocular CCD camera and inertial-sensor for range estimation// IECON 02 [Industrial Electronics Society, IEEE 2002 28th Annual Conference of the]. IEEE, 2191-2196 vol.3, 2002.

13. H. M. Oluseyi, J. H. Bercovitz, A. Karcher, et al. LBNL four-side buttable CCD package development// Sensors and Camera Systems for Scientific, Industrial, and Digital Photography Applications V. Sensors and Camera Systems for Scientific, Industrial, and Digital Photography Applications V, 87-98, 2004.

14. G. D. Smith, K. E. Newton, L. Altherr. Hydrofluoric acid pre-treatment of matte artists' paints for binding medium analysis by Fourier transform infrared microspectroscopy. Vibrational Spectroscopy, 81:46-52, 2015.

15. B. H. Amundsen, H. V. Thomas, E. Thor, et al. Noninvasive myocardial strain measurement by speckle tracking echocardiography: Validation against sonomicrometry and tagged magnetic resonance imaging. Journal of the American College of Cardiology, 47(4):789-93, 2006.

16. K. Camera, K. H. So, R. W. Brodersen. An integrated debugging environment for reprogrammble hardware systems. Proceedings of the 6th International Symposium on Automated and Analysis-Driven Debugging, AADEBUG 2005, 111-116, 2005.

17. K. Itatani, T. Okada, T. Uejima, et al. Intraventricular Flow Velocity Vector Visualization Based on the Continuity Equation and Measurements of Vorticity and Wall Shear Stress. Japanese Journal of Applied Physics, 52(7S):1044-1055, 2013.

18. S. Charleston-Villalobos, R. González-Camarena, G. Chi-Lem, et al. Crackle sounds analysis by empirical mode decomposition. Nonlinear and nonstationary signal analysis for distinction of crackles in lung sounds. IEEE Engineering in Medicine \& Biology Magazine the Quarterly Magazine of the Engineering in Medicine \& Biology Society, 26(1):40-7, 2007.

19. L. Chen, Z. L. Tian, M. C. Gao, et al. Researches on Rules of the Longitudinal Residual Stress Distribution in Straightening Deformation Zone of Heavy Rail with Multi-Rollers. Physical \& Numerical Simulation of Materials Processing, 575-578:231-236, 2008.

20. T. Yonezawa, T. Maeguchi, T. Goto, et al. Quantitative Residual Strain Analyses on Strain Hardened Nickel Based Alloy// 15th International Conference on Environmental Degradation of Materials in Nuclear Power Systems-Water Reactors. John Wiley \& Sons, Inc., 1759-1771, 2012.

21. M. F. Lee, G. S. Chen, J. C. Wang. Using Affective Computing to Detect Emotions with Color// Frontier and Innovation in Future Computing and Communications. Springer Netherlands, 337-345, 2014. 
22. McNeill et al. Estimation of stress intensity factor by digital image correlation. Engineering Fracture Mechanics, Volume 28, Issue 1, Pages 101-112, 1987.

23. M. Miyara, Y. Yoshioka, A. Kitoh, et al. Functional delineation and differentiation dynamics of human CD4+ T cells expressing the FoxP3 transcription factor. Immunity, 30(6):899-911, 2009.

24. J. O. Rinne, D. J. Brooks, M. N. Rossor, et al. 11C-PiB PET assessment of change in fibrillar amyloid-beta load in patients with Alzheimer's disease treated with bapineuzumab: a phase 2, double-blind, placebocontrolled, ascending-dose study. Lancet Neurology, 9(4):363-372, 2010.

25. B. Frode. Vikebø, Àse Husebø, Aril Slotte, et al. Effect of hatching date, vertical distribution, and interannual variation in physical forcing on northward displacement and temperature conditions of Norwegian springspawning herring larvae. Ices Journal of Marine Science / Journal Du Conseil, 67(2):1948-1956, 2010.

26. M. Ureshi, T. Matsuura, I. Kanno. Stimulus frequency dependence of the linear relationship between local cerebral blood flow and field potential evoked by activation of rat somatosensory cortex. Neuroscience Research, 48(48):147-53, 2004. 


\section{LIST OF FIGURES AND TABLES:}

Fig. 1. Speckle pattern of a specimen

Rys. 1. Wzór plamkowy próbki

Fig. 2. The longitudinal stress distribution along $\mathrm{X} 1 \mathrm{X} 1$ at the point of $\mathrm{Y}=22$ (when the welding line is perpendicular to the crack direction)

Rys. 2. Rozkład naprężeń wzdłużnych wzdłuż X1X1 w punkcie Y=22 (gdy linia spawania jest prostopadła do kierunku pęknięcia)

Fig. 3. Changes of the value of longitudinal residual stress on the surface of specimen A

Rys. 3. Zmiany wartości naprężeń wzdłużnych własnych na powierzchni próbki A

Fig. 4. Changes of the value of longitudinal residual stress on the surface of specimen $B$

Rys. 4. Zmiany wartości naprężeń wzdłużnych własnych na powierzchni próbki B

Fig. 5. Changes of the value of longitudinal residual stress on the surface of specimen $\mathrm{C}$

Rys. 5. Zmiany wartości naprężeń wzdłużnych własnych na powierzchni próbki C

Note: figure $U$ describes the displacement component cloud picture of the specimen on $X$ direction; figure $V$ describes the displacement component cloud picture of the specimen on Y direction; figure Mises strain describes the Mises strain figure; figure Exx, Eyy and Exy are strain component cloud pictures

Uwaga: Rysunek $U$ opisuje zdjęcie chmury składowej przemieszczenia próbki $w$ kierunku X; rysunek $V$ opisuje zdjęcie chmury składowej przemieszczenia próbki w kierunku $Y$; rysunek naprężenia zredukowanego von Misesa (Mises strain) opisuje rysunek naprężenia zredukowanego von Misesa; rysunki Exx, Eyy i Exy to zdjęcia chmur skladowych naprężenia

Fig. 6. K-r curves

Rys. 6. Krzywe K-r

Fig. 7. CTOD value distribution of $10 \mathrm{~mm}$ specimens

Rys. 7. Rozkład wartości rozwarcia wierzchołka szczeliny CTOD $10 \mathrm{~mm}$ próbek

Tab. 1. Welding parameters

Tab. 1. Parametry spawania

Tab. 2. Residual stress measured value of specimen A (unit: MPa)

Tab. 2. Zmierzona wartość naprężenia własnego próbki A (jednostka: MPa)

Tab. 3. Measured value of residual stress of the specimen B (unit: MPa)

Tab. 3. Zmierzona wartość naprężenia własnego próbki B (jednostka: MPa)

Tab. 4. Measured value of residual stress of specimen C (unit: MPa)

Tab. 4. Zmierzona wartość naprężenia własnego próbki C (jednostka: MPa) 


\section{BADANIA MATERIALU POD KĄTEM ZLAMANIA Z ODERWANIA I PRZEMIESZCZENIA OTWORU SZCZELINY W OPARCIU O METODĘ CYFROWEJ KORELACJI OBRAZÓW}

Slowa kluczowe: metoda cyfrowej korelacji obrazów, szczelina, złamanie, spawanie.

\section{STRESZCZENIE:}

Spawanie, jako technologia procesu obróbki skrawaniem i produkcji, łączy materiały poprzez podgrzewanie materiałów zanim wysoka temperatura je stopi, a następnie chłodzi. Jego zaletą jest szeroki zakres zastosowań, łatwość obsługi, niskie koszty, itd. Jest ono stosowane w różnych dziedzinach, takich jak budowa statków, samolotów i innych dużych urządzeń produkcyjnych, produkcji miniaturowej elektroniki i różnego rodzaju płytek drukowanych, itp., co uczyniło nasze życie ogromnie wygodnym.

Jednak spawanie może spowodować wiele wad, jeżeli zaistnieje jakikolwiek niewłaściwy proces technologiczny, który może obniżyć intensywność spawania części oraz wpłynąć na ich działanie. Ponadto przeciążenie lub błędy w działaniu podczas użytkowania mogą spowodować poważne wypadki. Poprzez analizę przyczyn różnych wypadków przy spawaniu, stwierdziliśmy, że głównym powodem inaktywacji uszkodzeń po spawaniu obciążanej części było złamanie materiałów. Mikroskopijne pęknięcie wewnątrz materiałów to początek powstawania obu wad w obszarze spawanego materiału oraz zmęczenia materiału spowodowanego przez zmienne obciążenie. W wyniku połączenia działania spawalniczych naprężeń własnych i zastosowanego obciążenia, pęknięcie stale się powiększa zanim nie stanie się mikroskopijnym pęknięciem. Następnie wciąż się rozszerza i w końcu prowadzi do złamania materiałów. Występowanie naprężeń własnych w spawanych elementach poważnie wpłynie na wydajność operacyjną konstrukcji. W związku z tym badanie wpływu spawalniczych naprężeń własnych na właściwości złamania materiałów ma ogromne znaczenie.

W porównaniu do innych technik eksperymentalnych, metoda cyfrowej korelacji obrazów jest eksperymentalną metodą mechaniczną, która jest bardziej zależna od komputera. W związku z tym szybki rozwój informatyki i technologii zapewnia jej większą podstawę składającą się z oprogramowania i sprzętu. W rezultacie metoda cyfrowej korelacji obrazów została zastosowana w różnych warunkach, takich jak wiele zastosowań, właściwości materiału, ekstremalne warunki środowiskowe, itp., których rola staje się coraz ważniejsza. Obiekty przetwarzania metody cyfrowej korelacji obrazów to seria obrazów powierzchni obiektu pod wpływem różnych obciążeń w skali szarości. Oznaczono istotność szarej intensywności rozmieszczonej losowo na powierzchni obiektu przed i po deformacji, przemieszczenie i złamanie na powierzchni obiektu według statystyk prawdopodobieństwa. Podczas przetwarzania jego pracy, po imporcie informacji o deformacji wysokiej jakości do komputera, obrazy plamkowe są potrzebne do przeprowadzenia odpowiednich obliczeń, aby uzyskać pełną informację na temat próbki przed i po deformacji.

Przyjmując austenityczną stal nierdzewną 304 jako obiekt do badań, w niniejszym artykule zbadano właściwości złamania części spawalniczych w rezultacie spawalniczego naprężenia własnego za pomocą techniki cyfrowej korelacji obrazów oraz uzyskano następujące wnioski:

Przeprowadzono test na rozciąganie w temperaturze pokojowej na każdej próbce i zebrano obrazy plamkowe na powierzchni każdej próbki za pomocą układu pomiarowego cyfrowej korelacji obrazu. Obrazy pola przemieszczenia i chmury pola oderwania na powierzchni każdej próbki uzyskano za pomocą przetwarzania obrazów plamkowych z użyciem oprogramowania VIC-2D. Poprzez analizę wyników każdego obrazu chmury, stwierdzono, że wraz ze 
wzrostem obciążenia, pole przemieszczenia próbek wzrastało stopniowo. Ponadto rozkład wartości złamania końcówki pęknięcia na powierzchni próbek było zgodne z rozkładem pola przemieszczenia, tj. oba wzrosły wraz ze wzrostem obciążenia.

Stosując oprogramowanie VIC-2D, w niniejszym artykule uzyskano dane pól przemieszczenia i złamania oraz obliczono wartości czynnika intensywności naprężeń końcówki pęknięcia każdej próbki w wyniku działania małego obciążenia. Wyniki pokazały, że podczas gdy próbki były pod wpływem małego obciążenia, spawalnicze naprężenie własne miało oczywiście wpływ na parametry ich złamań, tzn. gdy istniało naprężenie własne na powierzchni próbek poddawanych temu samemu obciążeniu, parametry złamania próbek wzrosły. To wykazało, że spawalnicze naprężenie rozciągające własne zredukowało wytrzymałość na rozciąganie materiału i miało wpływ na wydajność operacyjną materiału. Z drugiej strony, gdy zaistniało naprężenie ściskające na powierzchni próbek, parametry złamania były mniejsze niż naprężenie rozciągające własne, co wskazywało na to, że naprężenie ściskające własne poprawiło wytrzymałość materiału na rozciąganie oraz wydajność operacyjną materiału. Jednak gdy próbki były poddawane dużemu obciążeniu, wpływ spawalniczego naprężenia własnego na parametry złamań był podobny do sytuacji w przypadku małego obciążenia, podczas gdy działanie to nie było oczywiste. To wskazywało na to, że zastosowane obciążenie stało się głównym czynnikiem wpływającym na właściwości złamania materiału w czasie poddawania dużemu obciążeniu, podczas gdy wpływ spawalniczego naprężenia własnego nie był już istotny.

Pomimo uzyskanych wyników badań, nadal istnieją pewne braki w tym badaniu, które należy dalej zbadać i poprawić w przyszłych badaniach. W trakcie eksperymentu dokładność rozpoznawania kształtów pęknięć nie była precyzyjna i brakowało wartości teoretycznych lub standardowych w celu sprawdzenia dokładności. Obie te rzeczy powinny ulec dalszej poprawie. Teoretyczne badania nad metodą korelacji obrazów cyfrowych nie były wystarczające - w celu dalszej analizy zasad tego przemieszczenia i oderwania materiału do złamania, metoda powinna zostać rozszerzona, a algorytm poprawiony. Tymczasem skaningowy mikroskop elektronowy może być wykorzystany do obserwacji i analizy mikroprocesu uszkodzenia w wyniku złamania. Również przypadkowe błędy w procesie uzyskiwania obrazu nie zostały dogłębnie zbadane, więc były źródłem błędów w jakości obrazu plamkowego, zniekształcenia obiektywu, położenia źródła światła, szumu, itp., które powinny być dalej poprawiane w przyszłych badaniach. 